\title{
Review
}

\section{Current state of knowledge on Virilastacus species (Crustacea, Decapoda, Parastacidae)}

\author{
Erich H. Rudolph ${ }^{1}$ \\ ${ }^{1}$ Departamento de Ciencias Biológicas y Biodiversidad, Universidad de Los Lagos \\ P.O. Box 933, Osorno, Chile \\ Corresponding author: Erich H. Rudolph (erudolph@ulagos.cl)
}

\begin{abstract}
The genus Virilastacus was created in 1991 to accommodate Parastacus araucanius Faxon, 1914. At present, Virilastacus comprises four burrowing species, three of which were described at the beginning of the XXI century, and biological knowledge about these species is mainly limited to taxonomic and distributional aspects. This review compiles published information about these species, together with other data available to the author in order to update the current state of biological knowledge and, in turn, to promote the conservation of these species. An upgraded diagnosis of the genus Virilastacus is provided, together with information related to each species with regard to: distinctive morphological traits, geographic distribution, habitat, burrow morphology, burrowing behavior, body size, sexual system, and state of conservation. Some aspects related to morphological adaptations to their burrowing life style, phylogenetic affinities and main threats to conservation are also discussed. It is concluded that biological knowledge about these four species is scarce and fragmentary; furthermore, they are currently under threat as a result of anthropogenic activities that are degrading and fragmenting their habitat.
\end{abstract}

Keywords: Virilastacus, burrowing crayfish, morphology characters, geographic distribution, sexual system, habitat, conservation status, Chile.

\section{Estado de conocimiento de las especies de Virilastacus (Crustacea, Decapoda, Parastacidae)}

RESUMEN. El género Virilastacus fue creado en 1991 para ubicar a Parastacus araucanius Faxon, 1914. Actualmente Virilastacus reúne a cuatro especies excavadoras, tres de ellas descritas a comienzos del siglo XXI, cuyo conocimiento biológico se circunscribe principalmente a aspectos taxonómicos y distribución. Esta revisión recopila la información publicada de estas especies, junto a otros datos accesibles al autor, para actualizar el conocimiento biológico y a la vez promover su conservación. Se proporciona una diagnosis actualizada del género, y de cada especie se entrega información sobre: rasgos morfológicos distintivos, distribución geográfica, hábitat, morfología de las galerías, comportamiento excavador, tamaño corporal, sistema sexual y estado de conservación. También se comentan algunas de las adaptaciones morfológicas a su estilo de vida excavador, sus afinidades filogenéticas y las principales amenazas a su conservación. Se concluye que el conocimiento biológico de estas cuatro especies es escaso y fragmentario, y que ellas se encuentran amenazadas por actividades antropogénicas que están degradando y fragmentando su hábitat.

Palabras clave: Virilastacus, camarones excavadores, caracteres morfológicos, distribución geográfica, sistema sexual, hábitat, estado de conservación, Chile.

\section{INTRODUCTION}

At the beginning of the XX century, 10 species of the family Parastacidae had been described for South America, all grouped within one genus: Parastacus. Riek (1971) separated them into the genera Samastacus and Parastacus; he assigned two species [Parastacus spinifrons (Philippi, 1882) and Parastacus araucanius Faxon, 1914] to the genus Samastacus, in view of the following characteristics: P1 dactyls moving horizontally and phallic papillae being relatively long, articulated tubular projections. The other species, whose

Corresponding editor: Ingo Wehrtmann 
dactyls move vertically and phallic papillae are only small non-articulated protuberances, remained within Parastacus. Additionally, Riek (1971) characterized these genera in ecological terms: the Parastacus species as burrowers and inhabitants of underground waters, while the Samastacus species were characterized as weak burrowers, inhabiting rivers and lakes. After a period of 69 years, during which the only knowledge about Samastacus araucanius (Faxon, 1914) was based on the type specimen, Jara (1983) collected a second specimen, a male captured in the Botanical Gardens of the Universidad Austral de Chile (Valdivia), cohabitating with Parastacus nicoleti (Philippi, 1882). Rudolph \& Rivas (1988) collected the third representative of this species, also a male in Hualqui (Concepción) cohabiting with Parastacus pugnax (Poeppig, 1835). These discoveries provided sufficient evidence to exclude the occurrence of $S$. araucanius in open waters, as had been suggested in Faxon's (1914) description of the location where the type material was obtained: "in a waterfall in Corral". Based on this evidence, as well as on morphological differences [which were already mentioned by Jara (1983) and Rudolph \& Rivas (1988)], Hobbs (1991) separated these two species into the genera Samastacus (S. spinifrons) and Virilastacus (V. araucanius); this author also provided diagnoses of the three South American genera of Parastacidae. Crandall et al. (2000) validated these three genera, based on the sequencing of 500 nucleotides of the $16 \mathrm{~S}$ mitochondrial DNA gene in seven of the ten species of South American parastacids. Rudolph \& Crandall $(2005,2007,2012)$ described three new species of Virilastacus, extended their geographic range, and confirmed that all the species of this genus were burrowers. In the present review, the scarce information published on the Virilastacus species is compiled and systematized, together with other data available to the author, with the aim to update the biological knowledge about this species and, in turn, to promote effective conservation measures.

\section{Family Parastacidae Huxley, 1879}

Genus Virilastacus Hobbs, 1991

Diagnosis

Rostrum short. Carapace lacking spines, tubercules and postorbital ridges; anterolateral portion of branchiocardiac groove clearly separated from the portion subparallel to cervical groove, which is located close to upper third portion of cephalothorax. Viewed dorsally, cervical groove $\mathrm{V}$-shaped, except in $V$. retamali. Pleon lacking spines and tubercles; pleura of first abdominal segment distinct from and partly overlapped by that of the second abdominal segment. Telson without transverse suture and wholly calcified; posterior half with dorsomedian longitudinal groove. Ventral surface of ischipodite of third maxilliped bearing a median longitudinal band of tubercules; inside half of this surface with tufts of rigid setae; distolateral end of podomere rounded, except in $V$. jarai; merus lacking spines or tubercules; exopodite reaches distal end of merus. Caudal molar process of mandible quadricuspid in $V$. araucanius and $V$. jarai; tricuspid in $V$. rucapihuelensis and $V$. retamali; nodular cusp on proximal margin of cuspidal triangle. P1 chelae dimorphic, with almost completely tuberculated palms, but lacking spines or large tubercules; ventrolateral borders tuberculated to slightly subtoothed; carpus lacking large tubercules medially or ventrally, when upper surface held in a horizontal plane, dactyl moving obliquely in $V$. rucapihuelensis and $V$. jarai, and subhorizontally in $V$. araucanius and $V$. retamali. No occurrence of male and female gonopores in the same individual, except in $V$. rucapihuelensis. Male genitalia with a semi-rigid, tubular, thin, articulated, and very long phallic papilla extending forward from coxae in very close proximity to each other; lacking male cuticle partition, except in V. rucapihuelensis. Sternite XIII with an anterior medial plate, and posterior orifice. Viewed caudally, lateral processes of sternite XIV separated by a pronounced vertical fissure.

Type species. Parastacus araucanius Faxon, 1914: 553 Gender: Male

Etymology. From the Latin virilis = masculine; socalled because of its comparatively long phallic papilla (Hobbs, 1991; Rudolph \& Crandall, 2012).

Virilastacus araucanius (Faxon, 1914) (Fig. 1a)

Common name: Dwarf crayfish

Synonymy

Parastacus araucanius Faxon, 1914: 353, pp. 4, Figs. 1-3; Van Straelen, 1942: 9; Holthuis, 1952: 84; Bahamonde \& López, 1963: 126 and 127, maps 1 and 2; Jara, 1983: R-163.

Samastacus araucanius Riek, 1971: 135; Manning \& Hobbs, 1977: 159; Rudolph \& Rivas, 1988: 73, Fig. 1; Hobbs, 1989: 80, Fig. 374; Buckup \& Rossi, 1993: 167, Figs 11-13; Martínez et al., 1994: 9, Figs. 1-11.

\section{Distinctive morphological characteristics}

Cephalothorax smooth, coloration: olive green. Small eyes. Rostrum short, reaching distal end of middle podomere of antennal flagellum; dorsally excavated. Rostral carina long and slightly prominent. Cervical groove weakly "V" shaped. Areola narrow and extended. Antennal scale short with one small distolateral spine. Basal podomere of antennula lacking 

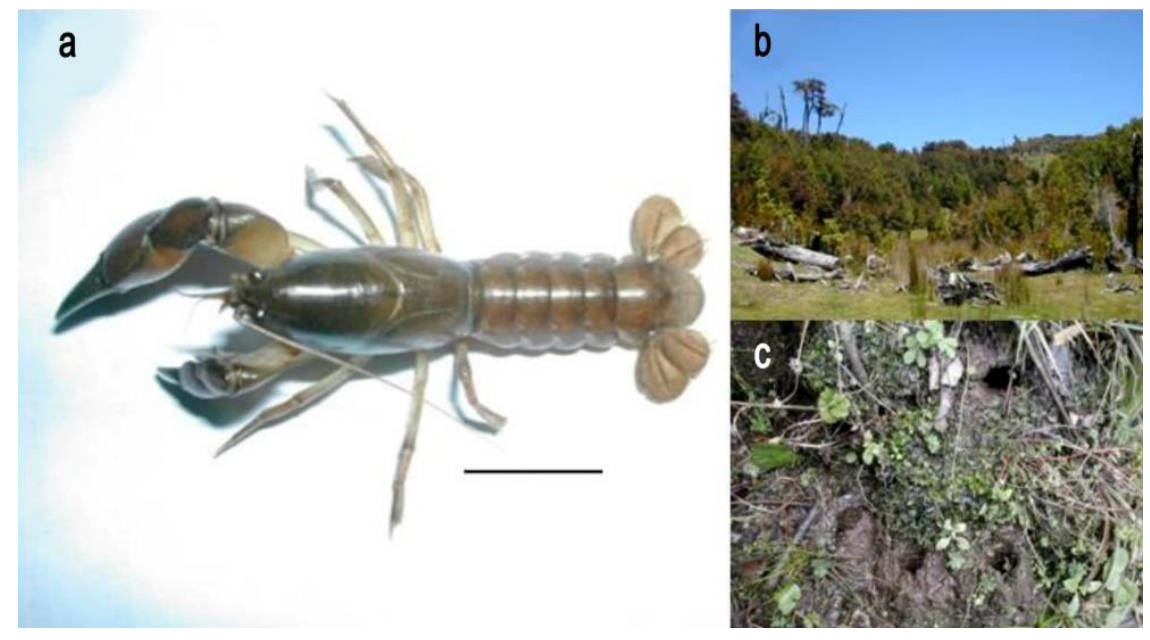

Figure 1. Virilastacus araucanius (Faxon, 1914). a) Dorsal view of male. Scale bar = $17.9 \mathrm{~mm}$, b) partial view of habitat, c) overhead view of chimneys. Photos: E. Rudolph.

spines. Opposable margin of propodite without pilosity, bearing 11 to 18 teeth; dactyl moving sub horizontally, opposable margin bearing nine to 15 teeth. Individuals with female or male gonopores. Elongated phallic papilla reaches base of lateral process of XII body segment. In males, P5 coxae lack cuticle partition. Pleon coloration light brown. Telson subrectangular, dorsomedian longitudinal groove, and prominent spine on each lateral border (Faxon, 1914; Riek, 1971; Hobbs, 1991; Rudolph \& Crandall, 2012). Species relatively small. The largest specimen caught is a female, measuring $28.7 \mathrm{~mm}$ cephalothorax length (CL) (74.8 $\mathrm{mm}$ total length). The smallest specimen collected is also a female, $18.3 \mathrm{~mm} \mathrm{CL}$ (Martínez et al., 1994). In the case of males, maximum and minimum sizes recorded are 26.0 and $19.0 \mathrm{~mm}$ CL respectively (Faxon, 1914; Jara, 1983). A summary of distinctive morphological features of the four species of Virilastacus is provided in Table 1.

\section{Geographic distribution}

$V$. araucanius has been recorded from areas surrounding Concepción (36 46'22”S, 7303'47'W), Valdivia $\left(39^{\circ} 48^{\prime} 30^{\prime \prime} \mathrm{S}, 73^{\circ} 14^{\prime} 30^{\prime \prime} \mathrm{W}\right)$, and Maicolpué (4036'27,74'S, 7344'01,44”W) (Faxon, 1914; Jara, 1983; Rudolph \& Rivas, 1988; Hobbs, 1991; Martínez et al., 1994; Bahamonde et al., 1998). This discontinuous distribution may only be apparent, since it coincides with the presence of university research centers in these three areas (Jara et al., 2006). Nevertheless, recordings of $V$. araucanius in Maicolpué (Bahamonde et al., 1998) should be reviewed, given that they may correspond to specimens of either $V$. rucapihuelensis or $V$. retamali, described after the studies of Bahamonde et al. (1998), in a location (Rucapihuel) situated only $15 \mathrm{~km}$ from Maicolpué. Finally, recordings of $V$. araucanius suggest that it is distributed between the coast and the Coastal Cordillera mountain range; the extent of occurrence is estimated at $11.571,64 \mathrm{~km}^{2}$ (Ministerio del Medio Ambiente, 2013a).

\section{Habitat}

$V$. araucanius inhabits underground waters in topographic basins with evergreen lowland forest associations. Almost all recordings of this species occur in these biotopes, commonly referred to as "vegas" or "hualves" (Fig. 1b). Only the discovery of $V$. araucanius in the Botanical Gardens of the Universidad Austral de Chile in Valdivia (Jara, 1983; Hobbs, 1991) indicates its presence in flatter zones, subject to considerable anthropic intervention. Specimens of this species have also been found coexisting with $P$. nicoleti (Jara, 1994; Jara et al., 2006) in the same Botanical Gardens. A similar situation occurs in the locality of Hualqui (46 $\left.56^{\prime} \mathrm{S}, 72^{\circ} 55^{\prime} \mathrm{W}\right)$, where specimens of $V$. araucanius have been found cohabiting with $P$. pugnax (Rudolph \& Rivas, 1988).

\section{Burrow morphology}

The burrows constructed by $V$. araucanius are shallow $(<1 \mathrm{~m})$, but quite complex, with multiple ramifications, many of them almost parallel to the surface, which complicates their capture, whether manually or by suction methods. In winter, $V$. araucanius constructs mud "chimneys" 2.0-6.0 cm high, located around the entrance orifices of their burrows (Jara, 1994) (Fig. 1c). According to the classification of burrowing crayfish 
proposed by Hobbs (1942), V. araucanius would be a primary burrower, since it builds complex burrows are not connected to permanent water bodies, and the entire life cycle of this species occurs inside the burrows.

\section{Sexual system}

Descriptions of external sexual characteristics, together with some anatomical analyses of gonads and gonoducts, suggest that $V$. araucanius is a gonochoric species. Adult females have ellipsoidal gonopores, partially surrounded by setae and covered by a noncalcified membrane. These characteristics, suggesting the occurrence of functional gonopores, are very similar to those observed in $V$. rucapihuelensis adult females (Rudolph et al., 2007). Males have an elongated, calcified phallic papilla $(\overline{\mathrm{X}}=3.1 \pm 0.4 \mathrm{~mm}$; $\mathrm{n}=12$ ) and the respective gonopore opens at the apical end (Rudolph \& Rivas, 1988; Hobbs, 1991; Martínez et al., 1994; Rudolph \& Almeida, 2000).

\section{Conservation status}

Bahamonde et al. (1998) categorized $V$. araucanius as Insufficiently Known throughout its entire geographic range. Nevertheless, they warned that water pollution and substrate modification within its distribution area could cause negative effects on the conservation of these populations. Rudolph \& Crandall (2007) classified the species as Vulnerable through its geographic distribution range, based on the $\mathrm{B} 1 \mathrm{ab}$ (iii) criteria of the IUCN Red List (2001). Buckup (2010a) classified it as Data Deficient. The Ministerio de Medio Ambiente (2013a) described it as Vulnerable, in accordance with the B $1 \mathrm{ab}$ (iii) + $2 \mathrm{ab}$ (iii) criteria of the IUCN Red List (2001). Finally, Almerao et al. (2014) also endorsed this latter categorization.

Virilastacus rucapihuelensis Rudolph \& Crandall, 2005 (Fig. 2a)

Common name: Vega crayfish

Synonym: Virilastacus araucanius Rudolph \& Rojas, 2003: 835, Figs. 1-8

\section{Distinctive morphological characteristics}

Cephalothorax with small tubercles only in anteroventral regions of branchiostegites. Small eyes. Rostrum short, reaching distal margin of basal podomere of antennal flagellum; dorsally concave. Rostral carina long and prominent. Epistome anteromedian lobe resembles a triangle. Cervical groove "V" shaped. Basal podomere of antennula with small spine. Dorsal surface of P1 carpus with faint median groove, opposable margin of propodite bearing 5 to 9 teeth with pilosity on both sides, but only of their proximal group, dactyl moving obliquely. Abdominal pleura ventral

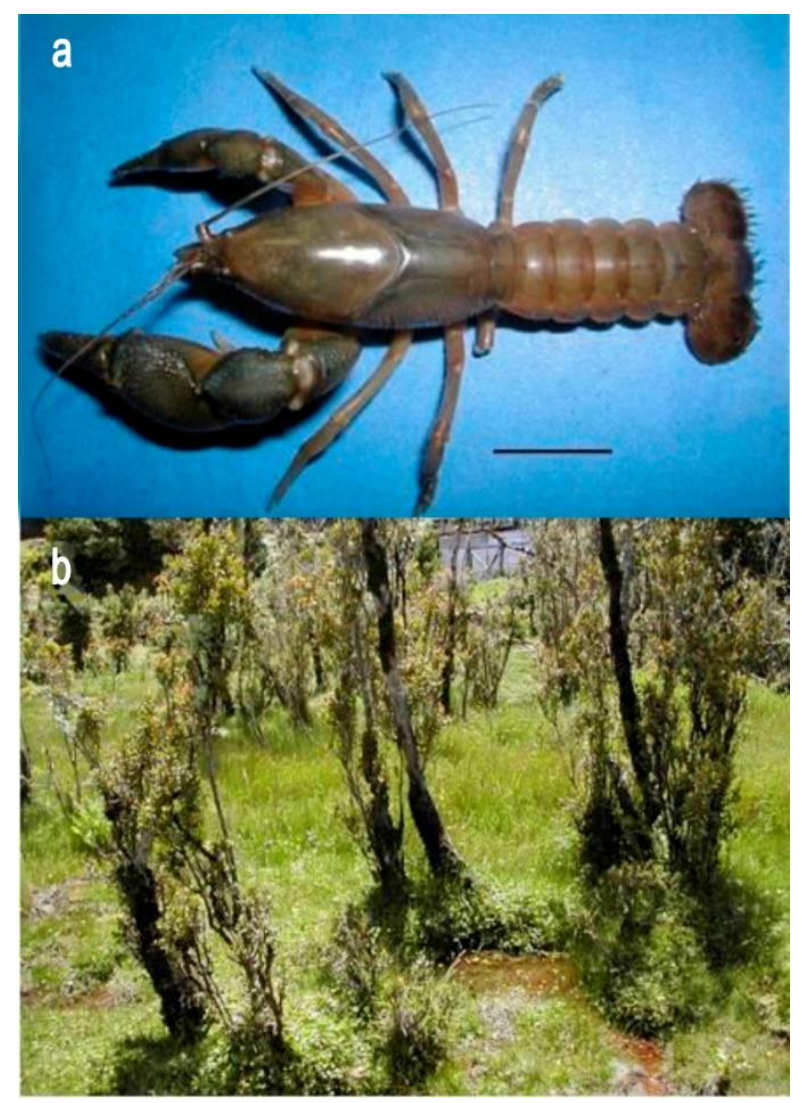

Figure 2. Virilastacus rucapihuelensis Rudolph \& Crandall, 2005. a) Dorsal view of specimen. Scale bar $=$ $14.0 \mathrm{~mm}, \mathrm{~b})$ partial view of habitat. Photos: E. Rudolph.

margins almost straight. Individuals with supernumerary gonopores. In adult females, pleura of second pleomere with wide anteroventral flap, weakly calcified. Males with slightly elongated phallic papillae that reach the base of the P4 coxae. In males, P5 coxae with cuticle partition. Telson subrectangular, lateral margins almost parallel, each of them with a small, blunt spine. Light brown body coloration (Rudolph \& Crandall, 2005, 2012). This species is slightly larger than $V$. araucanius. The largest specimen collected (33.6 $\mathrm{mm} \mathrm{CL}$ ) is an intersex individual in female phase and the smallest, a primary female with $4.4 \mathrm{~mm} \mathrm{CL}$ (Rudolph et al., 2007) (Table 1).

\section{Geographic distribution}

This species has been reported from five nearby sites in the Coastal Cordillera of the province of Osorno, southern Chile: Rucapihuel $\left(40^{\circ} 35^{\prime} 00.64^{\prime \prime} \mathrm{S}, 7^{\circ} 34^{\prime} 42\right.$. 96”W), Coiguería (40³5’17.62”S, 73³2’10.00”W), Carrico (40³5'34.14”'S, 73³1'19.70”W), Contaco $\left(40^{\circ} 36^{\prime} 01.50^{\prime \prime} \mathrm{S}, 73^{\circ} 31^{\prime} 00.97^{\prime \prime} \mathrm{W}\right)$, and Loma de la Piedra (4040'13.59”'S, 73³0'51.42”W) (Rudolph \& Crandall, 2005; Grosso \& Peralta, 2009). The extent of 
Table 1. Morphological characters useful for distinguish the four presently identified species of Virilastacus (Modified from Rudolph \& Crandall, 2012).

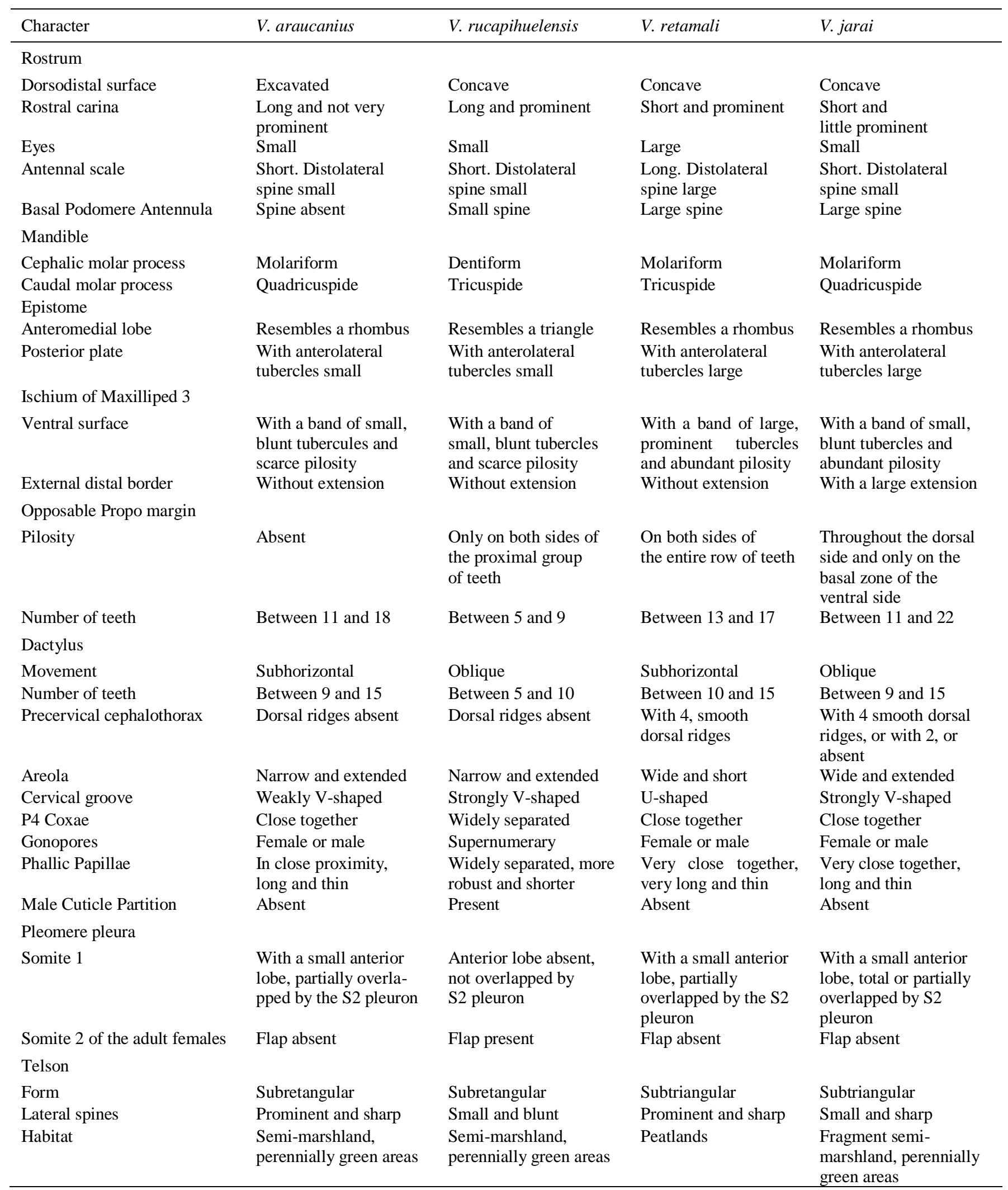


their occurrence covers $39.3 \mathrm{~km}^{2}$ (Ministerio de Medio Ambiente, 2013b).

\section{Habitat}

$V$. rucapihuelensis inhabits underground waters in biotopes locally called "vegas" or "hualves" (Rudolph \& Crandall, 2005) (Fig. 2b). The soil profile of the "vegas" located in Rucapihuel includes two layers composed of fine clay sand. The upper layer comprises abundant iron oxides, the lower layer $(80 \mathrm{~cm}$ below the soil surface) is of sandy gravel. In the winter, the phreatic level is close to or above the surface, and in summer, it descends as far as 1.0 or $1.5 \mathrm{~m}$ below the surface (Bedatou et al., 2010). After carrying out yearround monthly recordings of some physicochemical parameters of the water inside the burrows, Martínez (2005) verified that temperature fluctuated between 11 y $19^{\circ} \mathrm{C}$, pH between 4.1 and 5.3, and dissolved oxygen between 2.6 and $6.5 \mathrm{mg} \mathrm{L}^{-1}$; on the other hand, total hardness remained constant at $17.8 \mathrm{ppm}$ de $\mathrm{CaCO}_{3}$.

\section{Burrow morphology and burrowing behavior}

The burrow morphology is variable. Some have several relatively complex entrance orifices (diameter 2.5-3.5 $\mathrm{cm}$ ) with multiple ramifications in the subsoil. Some of these connected to a terminal chamber with a slightly larger diameter than the tunnel, situated between 1 and $1.2 \mathrm{~m}$ below the surface. Others are blind tunnels (Type 1 burrow, Fig. 3a). Other burrows have only one subvertical tunnel ( 3 to $4.5 \mathrm{~cm}$ diameter and up to 66 $\mathrm{cm}$ depth) with a few blind tunnels emerging from the uppermost section. The lower terminal section of this system is a sub-horizontal chamber with a slightly wider diameter than the tunnel (Bedatou et al., 2010) (Type 2 burrow, Fig. 3b). V. rucapihuelensis forms small pellets (8-10 $\mathrm{mm}$ maximum diameter) from the excavated material, and these pellets are deposited in the winter around the entry orifices of the burrows, forming "chimneys" of up to $12 \mathrm{~cm}$ height (Rudolph \& Crandall, 2005) (Fig. 3c), these burrows are usually inhabited by one specimen; nevertheless, in springsummer, it may be possible to find a female with a variable number of recently released juveniles in some of these burrows. According to Hobbs' (1942) classification, aspects such as excavating complex burrows, distanced from permanent water bodies, together with no recordings of specimens outside the burrows, suggest that this species can be considered as a primary burrower.

\section{Sexual system}

V. rucapihuelensis presents partial protandric hermaphroditism with primary males and females (Rudolph

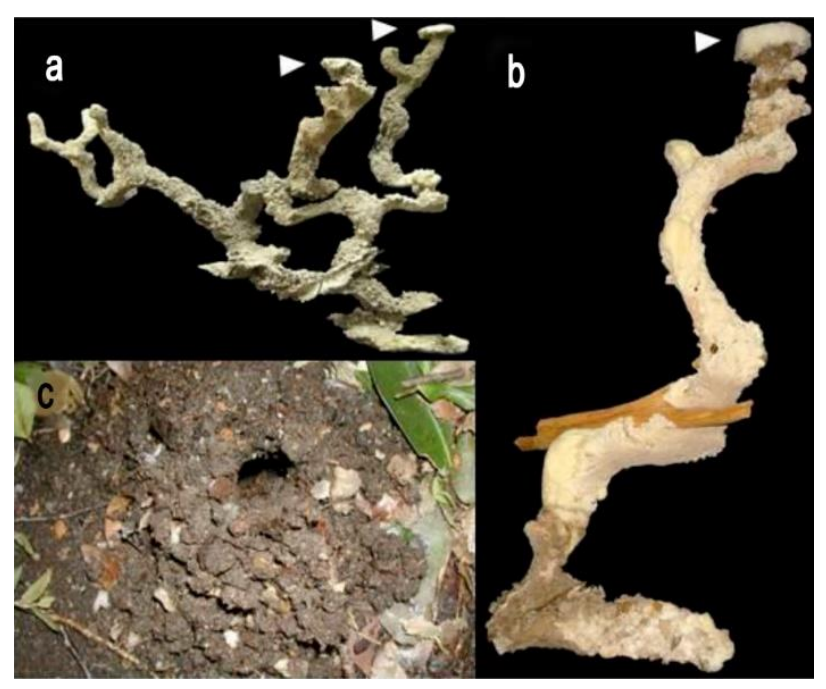

Figure 3. Virilastacus rucapihuelensis Rudolph \& Crandall, 2005. a) Lateral view of mould type 1 burrow, b) lateral view of mould type 2 burrows, c) overhead view of chimney. Arrowheads = surface entrances. Photos: a) and b) E. Bedatou; c) E. Rudolph.

et al., 2007). Depending on the presence or absence of gonopores in the P3 and P5 coxae; externally, six sexual forms may be distinguished. Anatomical analyses of the gonads and gonoducts of these sexual forms enabled us to ascertain the presence of three basic sexual types: primary males, primary females, and intersex specimens. These latter comprise one malephase and two female-phase forms, that would originate from male-phase intersex individuals (Rudolph $e t$ al., 2007).

\section{Fecundity}

The species produced up to 74 eggs, incubated by a primary female of $27.9 \mathrm{~mm} \mathrm{CL}$. The lowest fecundity (three eggs) observed was in a primary female of 23.1 mm CL (Rudolph et al., 2007).

\section{Conservation status}

Rudolph \& Crandall (2007), based on the B1 ab (iii) criteria of the IUCN Red List (2001), classified $V$. rucapihuelensis as Endangered in its entire distribution range, while Buckup (2010b) classified it as Data Deficient. The Ministerio de Medio Ambiente (2013b) classified it as Endangered, maintaining that it meets the B1 ab (iii) + $2 \mathrm{ab}$ (iii) criteria of the IUCN Red List (2001). Finally, Almerao et al. (2014) suggested that $V$. rucapihuelensis is Critically Endangered, considering that it falls within the B1 ab (iii) criteria associated with this category. 


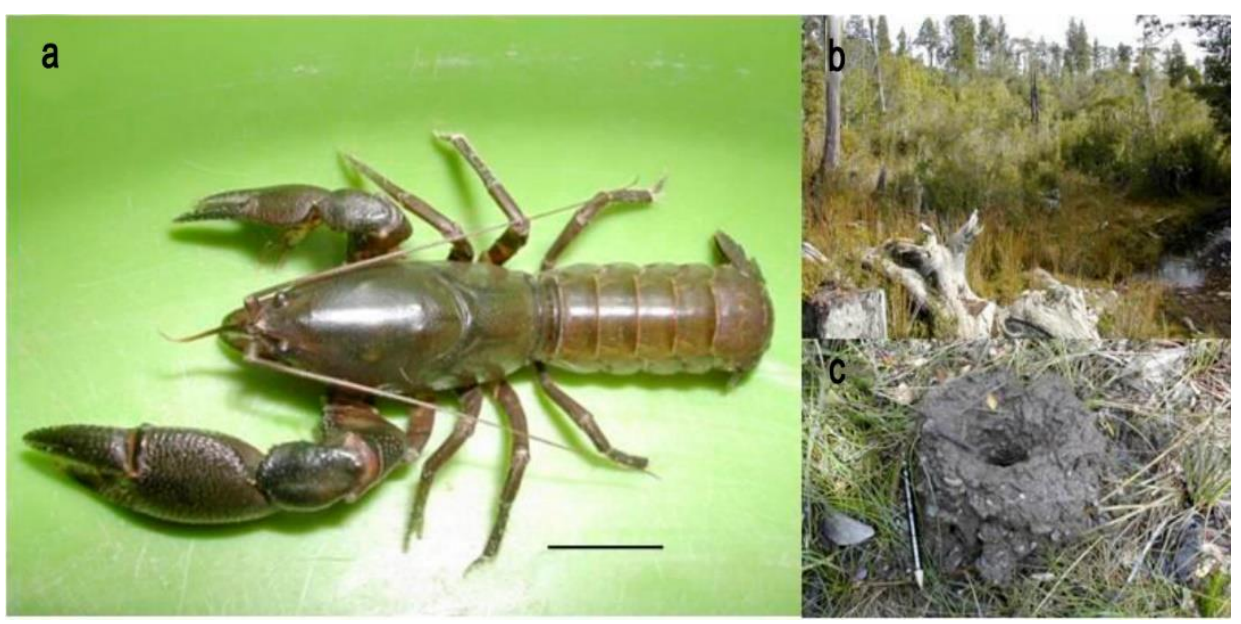

Figure 4. Virilastacus retamali Rudolph \& Crandall, 2007. a) Dorsal view of specimen. Scale bar $=12.0 \mathrm{~mm}$, b) partial view of habitat, c) lateral view of chimney. Photos: E. Rudolph.

\section{Virilastacus retamali Rudolph \& Crandall, 2007 (Fig. 4a) \\ Common name: Peatland crayfish}

\section{Distinctive morphological characteristics}

Precervical cephalothorax with four smooth ridges. Eyes comparatively large. Rostrum short reaches distal margin of middle podomere of antennal flagellum; dorsally concave. Rostral carina short and prominent. Cervical groove "U" shaped. Areola wide and short. Antennal scale long with large distolateral spine. Epistome anteromedian lobe resembling a rhombus. Basal podomere of antennula with large spine. Opposable margin of $\mathrm{P} 1$ propodite bearing 13 to 17 teeth, with pilosity on both sides of the row of teeth. Dactyl moving subhorizontally. Abdominal pleura with rounded ventral margins. Telson with converging lateral margins resembling a triangle, with prominent, sharp marginal spines. Individuals with female or male gonopores. Phallic papillae very elongated, reaching as far as the base of the $\mathrm{P} 3$ coxae. Males without cuticular partition in P5 coxae. Cephalothorax dark-olive green and pleon light olive green (Rudolph \& Crandall, 2007, 2012). Species is small (17.9-30.0 mm CL; $\overline{\mathrm{X}}=21.1 \pm$ $3.0 \mathrm{~mm} \mathrm{CL} ; \mathrm{n}=21$ ), but the only size data available derives from the type series specimen (Rudolph \& Crandall, 2007) (see Table 1).

\section{Geographic distribution}

This parastacid, recorded in two Coastal Cordillera localities in the provinces of Osorno and Llanquihue,

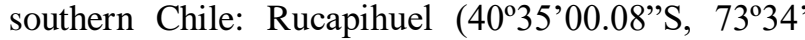
$\left.44.3^{\prime \prime} \mathrm{W}\right)$, and Estaquilla $\left(41^{\circ} 25^{\prime} 15.93^{\prime \prime} \mathrm{S}, 73^{\circ} 46^{\prime} 51\right.$. 74"W) (Rudolph \& Crandall, 2007) extends its occurrence approximately $3.200 \mathrm{~km}^{2}$ (Rudolph, 2010).

\section{Habitat}

Both of these $V$. retamali populations inhabit geogenous peatlands, i.e., depend on rainwater and superficial underground waters to supply hydric needs (Kulzer \& Cook, 2001). These peatlands originated in a small endorreic basin generated by the holocenic deglacialization where, over the course of time, organic matter has been deposited (Grignola \& Ordoñez, 2002). This organic material originated from the partially decomposed, loosely compacted vegetal remains of the genus Sphagnum, mixed with woody fragments, gramineous and humus particles, accumulated in an anoxic environment, highly saturated with water all year round (Grignola \& Ordoñez, 2002) (Fig. 4b). On capturing the type series, (17 December 2002), the water analyzed inside the burrows had a $\mathrm{pH}$ of 4.7 , dissolved oxygen of $2.8 \mathrm{mg} \mathrm{L}^{-1}$, constant hardness of $17.8 \mathrm{ppm}$ of $\mathrm{CaCO}_{3}$, and a temperature of $12.5^{\circ} \mathrm{C}$ (Rudolph \& Crandall, 2007).

\section{Burrow morphology}

Virilastacus retamali excavates shallow burrows (45 $\mathrm{cm}$ depth approximately) with few ramifications. A mold made with polyester resin (Bedatou et al., 2010) revealed six main entrances, with diameters ranging from 3.0 to $3.5 \mathrm{~cm}$. Fifteen centimeters below the surface, three of these entrances converged into a short, subhorizontal tunnel; one of its ends projected slightly upwards to form a short blind tunnel; the other extreme is connected to a main sub-horizontal tunnel. The remaining three entrances converged at a depth of 30 $\mathrm{cm}$, at the other end of the main tunnel. In the winter, the species constructs "chimneys" reaching an average height of $3.9 \mathrm{~cm}(\mathrm{SD}= \pm 0.729 ; \mathrm{n}=8)$ (Fig. 4c). Unlike the other species of the genus, $V$. retamali has been observed and captured outside its burrows, in nearby 
surface pools. Based on these observations and according to Hobbs's criteria (1942), V. retamali can be categorized as a secondary burrowing species (Rudolph \& Crandall, 2007).

\section{Sexual system}

No external morphological evidence of intersexuality has been detected in the type series (Rudolph \& Crandall, 2007), suggesting that this species is gonochoric. Females smaller than $20.0 \mathrm{~mm}$ CL have strongly calcified semi-ellipsoidal gonopores, while females larger than $20.0 \mathrm{~mm} \mathrm{CL}$ have apparently functional ellipsoidal gonopores, given that they are only partially calcified and surrounded by abundant pilosity. Males have a very elongated phallic papilla $(\overline{\mathrm{X}}=3.5 \pm 0.5 \mathrm{~mm})$ (Rudolph \& Crandall, 2007).

\section{Conservation status}

Rudolph \& Crandall (2007) classified V. retamali as an Endangered throughout its entire geographic range, given that it would meet the $\mathrm{B} 1 \mathrm{ab}$ (iii) criteria of the IUCN (2001) Red List for this category. Nevertheless, Buckup (2010c) classified it as Data Deficient, while Almerao et al. (2014) supported the endangered species classification of Rudolph \& Crandall (2007).

Virilastacus jarai Rudolph \& Crandall, 2012 (Fig. 5a)

Common name: Angeline crayfish

\section{Distinctive morphological characteristics}

Precervical cephalothorax with four, two or lacking smooth dorsal ridges. Eyes small. Rostrum short, reaching distal margin of the middle podomere of antennal flagellum; dorsally concave. Rostral carina short, weakly prominent. Epistome anteromedial lobe resembling a rhombus. Cervical groove "V" shaped. Areola wide and extended. Opposable margin of P1 propodite bearing 11 to 22 teeth with pilosity along the length of dorsal side, while only on basal part of ventral side. Dactyl moving obliquely. Abdominal pleura with straight ventral margins. Telson subtriangular with a small, sharp spine in each lateral margin. Individuals with female or male gonopores. Phallic papillae elongated, reaching base of lateral process of XII body segment. Males lacking cuticular partition in P5 coxae. Cephalothorax and P1 chelipeds olive green. Pleon and caudal fan light brown (Rudolph \& Crandall, 2012). It is a small species; size in the type series ranges from 6.7 to $24.8 \mathrm{~mm} \mathrm{CL}$ ( $\overline{\mathrm{X}}=17.5 \pm 6.1 \mathrm{~mm}$ ) (Rudolph \& Crandall, 2012) (see Table 1).

\section{Geographic distribution}

Virilastacus jarai has only been recorded in the type locality, a fragment of wetland situated in the "El Porvenir" sector $\left(37^{\circ} 26^{\prime} 39.84^{\prime \prime}\right.$,, $\left.72^{\circ} 18^{\prime} 37.12^{\prime \prime} \mathrm{W}\right), 1.5$ $\mathrm{km}$ northwest of the town of Los Ángeles in centralsouthern Chile (Rudolph \& Crandall, 2012).

\section{Habitat}

The species inhabits the underground waters of a fragment of semi-marshland, located in a topographic basin of $861 \mathrm{~m}^{2}$ at $152 \mathrm{~m}$ above sea level. This area is flooded for six months of the year (May to October) and the phreatic level remains below the surface in springsummer (Fig. 5b). The soil, characterized by a large accumulation of organic material, in addition to the high percentage of moisture originating from partially decomposed vegetal remains. On capturing the type series (13 June 2010), analysis of the water inside the burrows was as follows: dissolved oxygen $=4.9 \mathrm{mg} \mathrm{L}^{-1}$, temperature $=14.1^{\circ} \mathrm{C}, \mathrm{pH}=6.5$, and constant hardness of $53.4 \mathrm{ppm}$ of $\mathrm{CaCO}_{3}$ (Rudolph \& Crandall, 2012).

\section{Burrowing behavior}

The species excavates shallow $(<1 \mathrm{~m})$, but complex burrows, not connected to lothic or lenthic waters (Rudolph \& Crandall, 2012). In winter, it also constructs "chimneys" around the entrance orifices of the burrows (Fig. 5c). Outside the burrows, no specimens have been found, which suggest that the entire life cycle of $V$. jarai occurs inside the burrows. According to the Hobbs's (1942) criteria, the species can be considered as a primary burrower.

\section{Sexual system}

The revision of the type series revealed the occurrence of an intersex individual; however, this is not sufficient evidence to maintain that this is a transitional stage of an eventual sex change or, even less likely, that the species presents some form of hermaphroditism. Consequently, the evidence available suggests that $V$. jarai would be a gonochoric species (Rudolph \& Crandall, 2012).

\section{Conservation status}

Rudolph \& Crandall (2012) categorized V. jarai as Critically Endangered. This conclusion was based on the B1ab (ii) criteria of the IUCN Red List (2001) for this category, i.e., an estimated extent of occurrence of less than $100 \mathrm{~km}^{2}$, only known recording in one location, and a projected decline in habitat quality. The $V$. jarai habitat has been subject to deforestation in the recent past to clear land for agricultural purposes. At present, this land has been divided up and the topography modified to accommodate building development projects resulting from the rapid expansion of the town of Los Ángeles. Almerao et al. (2014) endorsed categorizing $V$. jarai as a critically endangered species. 

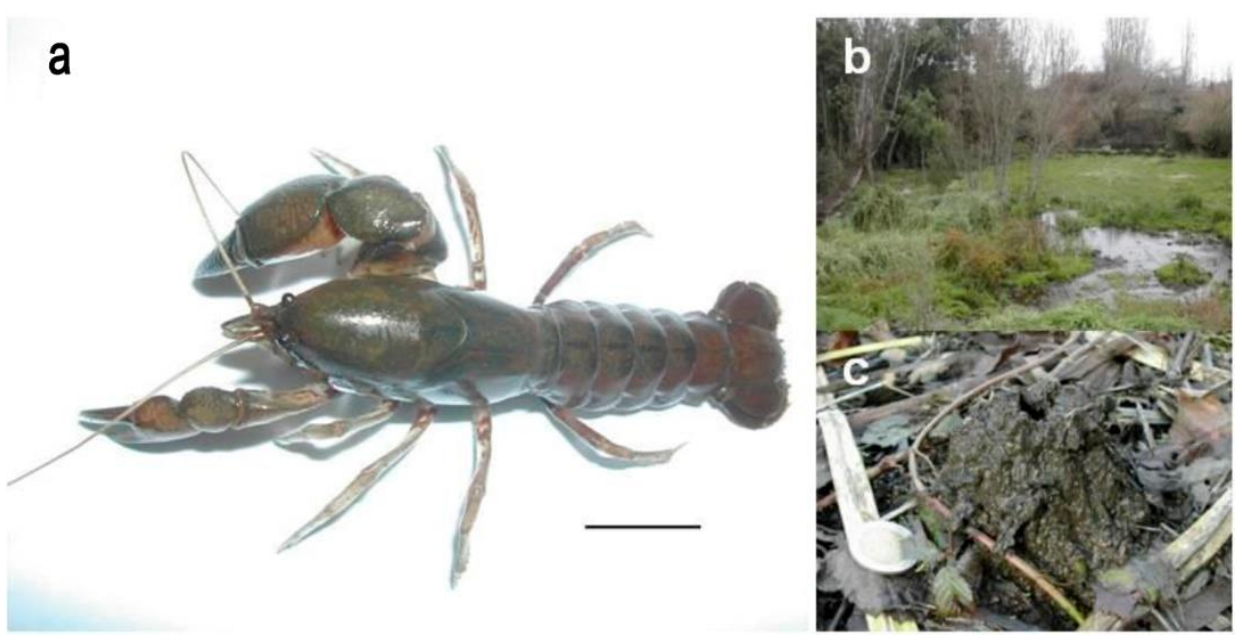

Figure 5. Virilastacus jarai Rudolph \& Crandall, 2012. a) Dorsolateral view of specimen. Scale bar $=9.0 \mathrm{~mm}$, b) partial view of habitat, c) lateral view of chimney. Photos: E. Rudolph.

\section{REMARKS}

The four Virilastacus species are endemic to Chile and have a restricted geographic range, distributed between the coastline and the Coastal Cordillera, from Concepción $\left(36^{\circ} 46^{\prime} \mathrm{S}\right)$ to Estaquilla $\left(41^{\circ} 25^{\prime}\right.$ 'S), except for $V$. jarai, whose presence has only been recorded in one location, to the east of the coastal Cordillera (Fig. 6). Furthermore, within this coastal fringe, populations present a clearly discontinuous distribution, associated with wetlands. These species are burrowers, and although their burrows are shallow $(<1.5 \mathrm{~m})$, have multiple ramifications and are much elaborated (Bedatou et al., 2010). The most significant morphological adaptations to this life style include the following aspects: (1) body without large protuberances, facilitating their movement inside the tunnels; (2) highly developed cephalothorax, in comparison to the scarcely developed pleon; (3) cephalothorax taller than broad, which increases the volume of the branchial chamber and makes it possible to house larger branchia than those species that inhabit open waters; (4) P1 chelae relatively large and vertically orientated, and (5) reduced eye size (Rudolph, 1997; Reynolds et al., 2013). They also share some biological characteristics of all freshwater astacids (Families Astacidae, Cambaridae and Parastacidae) such as: low fecundity, direct development with hatching in the juvenile stage, extended parental care up to the second juvenile stage, as well as omnivorous feeding habits (Rudolph \& Rojas, 2003; Rudolph, 2013). Like the other species of these three families, they are very important functional elements in the linmic ecosystems, both as prey and as consumers (Jara et al., 2006; Almerao et al., 2014). Nevertheless,

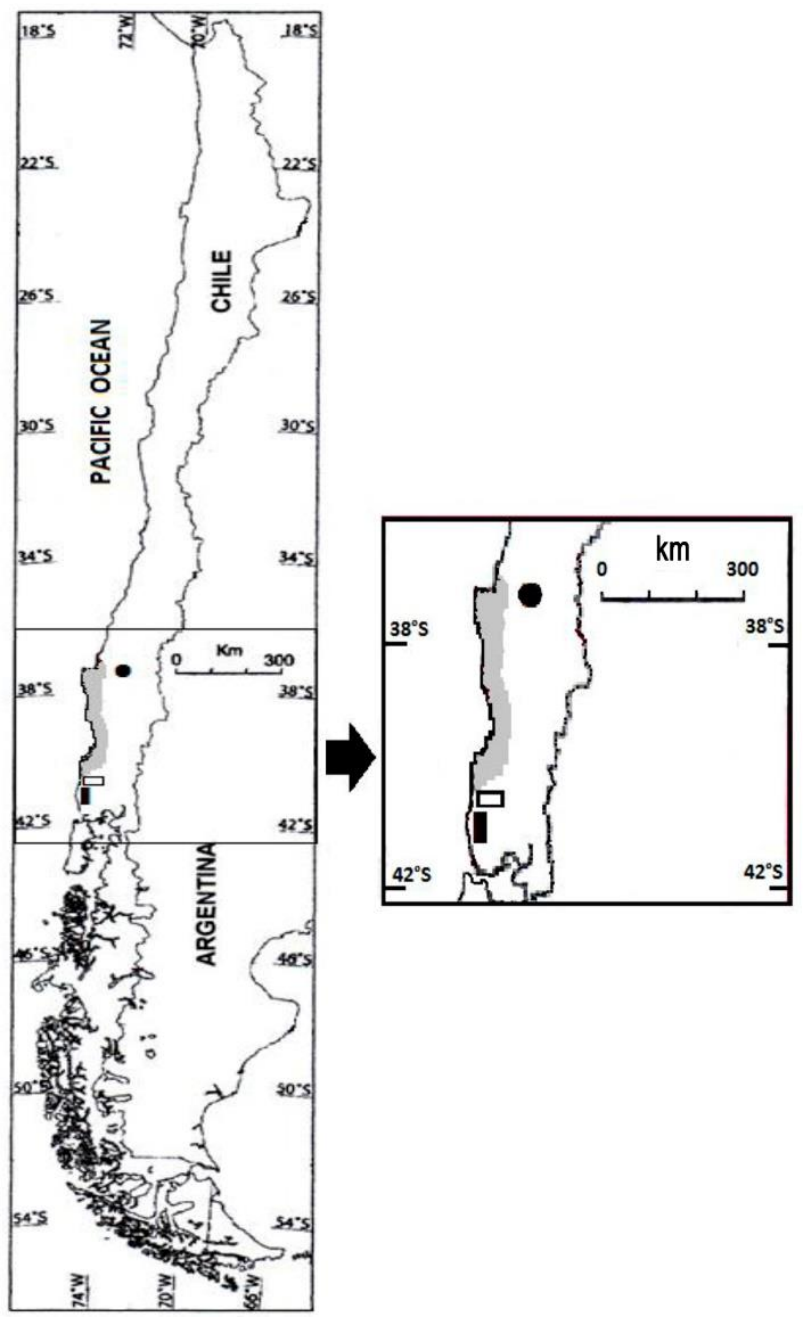

Figure 6. Geographical distribution of Virilastacus species. Gray fringe = Virilastacus araucanius; $\bullet$ Virilas tacus jarai; $\square$ Virilastacus rucapihuelensis; Virilastacus retamali. 
biological knowledge about these species is limited mainly to taxonomic and distributional aspects, with some information about their sexual system. Three of the four species have separate sexes while $V$. rucapihuelensis presents partial protandric hermaphroditism, with primary males and females (Rudolph et al., 2007). Similarly, some information has been acquired about their phylogenetic affinities (Rudolph \& Crandall, 2007, 2012). Reconstruction of phylogenetic relationships revealed the monophyly of the Virilastacus genus and of each one of its species. Furthermore, they showed that there is clear genetic differentiation between $V$. jarai and the other species of the genus. Virilastacus jarai is situated in a different basal clade with respect to the clade of the other three species, with $V$. araucanius being the species phylogenetically closest to $V$. jarai. Moreover, the incubation period of $V$. rucapihuelensis and probably that of the other three species extends from mid-winter to mid-summer (from July to February) (Rudolph et al., 2007). Recently, the Ministerio del Medio Ambiente (2013a, 2013b) and Almerao et al. (2014), based on the IUCN (2001) Red List criteria, have reevaluated and updated the state of conservation of Chilean and South American parastacids, respectively. Notwithstanding these updates, no effective measures for their protection have been implemented yet and, as a result, the conservation of the Virilastacus species is still under threat. Included among these threats are: (1) drainage of the "vegas" for forestry, farming and livestock development; (2) use of chemicals (agricultural fertilizers and pesticides); (3) clearing of vegetation and subsequent replacement of vegetation coverage; (4) free-range pig farming, which removes the original vegetation and compacts the soil, and (5) cattle farming, with trampling and destruction of the burrows. These threats are degrading, fragmenting, and ultimately decreasing the geographical extension of their habitat. Furthermore, certain intrinsic characteristics of parastacids [i.e., slow growth, low fecundity, delayed sexual maturity and long periods of embryonic and early post-embryonic development (Holdich, 1993; Rudolph, 2013)], together with the restricted geographic range and scarce mobility of the Virilastacus species, render them particularly vulnerable to the aforementioned threats. At present, the Chilean parastacids in general, and the Virilastacus species in particular, are not threatened by invasive exotic species (Rudolph, 2013). However, this threat could materialize in the near future, if we consider that Procambarus clarkii (Girard, 1852), a species native to North America and with considerable adaptive plasticity, has been introduced successfully to almost all continents, and has already been recorded in Colombia, Ecuador and Brazil (Valencia-López et al.,
2012; Almerao et al., 2014). Furthermore, recent studies revealed numerous areas in the southern cone of South America (Argentina, Paraguay, Uruguay, and Chile) suitable for P. clarkii occupation (Palaoro et al., 2013). Fortunately, these four species are not under threat from fishery activities for human consumption, because they are small species whose edible part (the pleon) is underdeveloped, thus, meat yield is very meager; these species also construct very complex burrows and considerable effort is required to capture them. Finally, part of their geographic range is located to the south of the Tolten River $\left(39^{\circ} \mathrm{S}\right)$, where the local inhabitants have no tradition of consuming these types of crustaceans. Could this lack of socio-economic significance account for the lack of legislation regulating their protection? Probably not considering that other Chilean parastacids exposed to elevated extraction pressure for human consumption purposes (i.e., Samastacus spinifrons and Parastacus pugnax) and neither is protected. Minimum biological knowledge (distribution range, habitat type, life style, size, incubation period, and state of conservation) necessary to establish regulations is now available. Legislation in this respect, together with regulating compliance with the law, would greatly contribute towards the conservation of Chilean parastacids. It is believed that protection of these species can be achieved, considering that the Ministry of Environment has announced a series of measures in both the National Plan of Action on Climate Change and the draft law for the creation of a Biodiversity and Protected Areas Service.

\section{ACKNOWLEDGEMENTS}

The author is grateful to the Research Department of the Universidad de Los Lagos, Osorno, Chile, for financially supporting many of the studies carried out on Virilastacus, in addition to the publication of this article. The collaboration of Susan Angus with the translation of the paper is appreciated.

\section{REFERENCES}

Almerao, M.P., E. Rudolph, C. Souty-Grosset, K. Crandall, L. Buckup, J. Amouret, A. Verdi, S. Santos \& P.B. Araujo. 2014. The native South American crayfishes (Crustacea, Parastacidae): state of knowledge and conservation status. Aquat., Conserv. Mar. Freshw. Ecosyst., 25(2). doi: 10.102/aqc. 2488.

Bahamonde, N. \& M.T. López. 1963. Decápodos de aguas continentales en Chile. Invest. Zool. Chil., 10: 123149.

Bahamonde, N., A. Carvacho, C. Jara, M. López, F. Ponce, M.A. Retamal \& E. Rudolph. 1998. Categorías 
de conservación de decápodos nativos de aguas continentales de Chile. Bol. Mus. Nac. Hist. Nat., 47: 91-100.

Bedatou, E., E. Rudolph, J.F. Genise, M. González \& R.N. Melchor. 2010. Architecture of burrows of extant land crayfishes from south-central Chile. Workshop on Crustacean Bioturbation - Fossil and Recent. Lepe, Spain, May 31-June 4, 2010, pp. 7-10.

Buckup, L. 2010a. Virilastacus araucanius. IUCN 2013. IUCN Red list of threatened species. Version 2013.2.

Buckup, L. 2010b. Virilastacus rucapihuelensis. IUCN 2013. IUCN Red list of threatened species. Version 2013.2.

Buckup, L. 2010c. Virilastacus retamali. IUCN 2013. IUCN Red list of threatened species. Version 2013.2.

Buckup, L. \& A. Rossi. 1993. Os Parastacidae do espaço meridional Andino (Crustacea, Astacidea). Rev. Bras. Biol., 53: 167-176.

Crandall, K.A., J.W. Fetzner, C.G. Jara \& L. Buckup. 2000. On the phylogenetic positioning of the South American freshwater crayfish genera (Decapoda: Parastacidae). J. Crustacean Biol., 20: 530-540.

Faxon, W. 1914. Notes on the crayfishes in the United States National Museum and the Museum of Comparative Zoology, with descriptions of new species and subspecies, to which is appended a catalogue of the known species and subspecies. Mem. Mus. Comp. Zool., Harv., 40: 347-427.

Grignola, P. \& A. Ordoñez. 2002. Perspectivas de utilización de los depósitos de turba de la isla de Chiloé. Décima Región de Los Lagos, Chile. Simposio Internacional de Geología Ambiental para Planificación del uso del Territorio, Puerto Varas, pp. 35-37.

Grosso, L.E. \& M. Peralta. 2009. A new Paraleptamphopidae (Crustacea, Amphipoda) in the burrow of Virilastacus rucapihuelensis (Parastacidae) and surrounding peat bogs. Rudolphia macrodactylus $\mathrm{n}$. gen., n. sp. from southern South America. Zootaxa, 2243: 40-52.

Hobbs, H.H. 1942. The crayfishes of Florida. U. Fla. Publ. Biol. Ser., 3: 1-79.

Hobbs, H.H. 1989. An illustrated checklist of the American crayfishes (Decapoda: Astacidae: Cambaridae, and Parastacidae). Smithson. Contrib. Zool., 480: 1-236.

Hobbs, H.H. 1991. A new generic assignment for a South American crayfish (Decapoda, Parastacidae) with revised diagnoses of the South American genera and comments on the parastacid mandible. Proc. Biol. Soc. Wash., 104(4): 800-811.
Holdich, D.M. 1993. A review of astaciculture: freshwater crayfish farming. Aquat. Living Resour., 6, 307-317.

Holthuis, L.B. 1952. The crustacean Decapoda Macrura of Chile. Reports of the Lund University Chile expedition 1948-49, Lunds Univ. Arssk, N.F. Avd. 2, Bd. 47, Nr. 10: 1-109.

International Union for Conservation of Nature (IUCN). 2001. IUCN Red list categories: Version 3.1. Gland, Switzerland: IUCN Species Survival Commission, 32 pp.

Jara, C.G. 1983. Segundo registro de Parastacus araucanius Faxon, 1914 (Crustacea: Decapoda: Macrura). Arch. Biol. Med. Exp., 16(2): 163-164.

Jara, C.G. 1994. Camarones dulceacuícolas en Chile. Informe técnico-científico, Instituto de Zoología, Universidad Austral de Chile, Valdivia, 15 pp.

Jara, C.G., E.H. Rudolph \& E.R. González. 2006. Estado de conocimiento de los malacostráceos dulceacuícolas de Chile. Gayana, 70(1): 40-49.

Kulzer, L. \& S. Cooke. 2001. Introducction. In: L. Kulzer, S. Luchessa, S. Cooke, R. Errington \& F. Weinmann (eds). Characteristics of the low-elevation Sphagnumdominated peatland of western Washington: a community profile. Part 1: Physical, chemical and vegetation characteristics. King County Water and Land Resources Division, Washington, pp. 1-15.

Manning, R.B. \& H.H. Hobbs, Jr. 1977. Decapoda. In: S.H. Hulbert (ed.). Biota acuática de Sudamérica austral. San Diego State University, San Diego, pp. 157-162.

Martínez, A.W. 2005. Revisión taxonómica del género Virilastacus Hobbs, 1991 (Crustacea, Decapoda, Parastacidae). Seminario de Título, Biología Marina, Universidad de Los Lagos, Osorno, 83 pp.

Martínez, R.I., F.E. Llanos \& A.E. Quezada. 1994 Samastacus araucanius (Faxon, 1914): aspectos morfológicos de un nuevo registro para Chile (Crustacea, Decapoda, Parastacidae). Gayana Zool., 58(1): 9-15.

Ministerio del Medio Ambiente (MMA). 2013a. Virilastacus araucanius. URL: [http://www.mma. gob.cl/clasificacionespecies/fichas10proceso/fichas_1 0_pac/Virilastacus_araucanius_10RCE_01_04_PAC. pdf]. Reviewed: 31 July 2015.

Ministerio del Medio Ambiente (MMA). 2013b. Virilastacus rucapihuelensis. URL: [http://www.mma.gob. cl/clasificacionespecies/fichas10proceso/fichas_10_pa c/Virilastacus_rucapihuelensis_10RCE_01_PAC.pdf]. Reviewed: 31 July 2015.

Palaoro, A.V., M.M. Dalosto, G.C. Costa \& S. Santos. 2013. Niche conservatism and the potential for the 
crayfish Procambarus clarkii to invade South America. Freshw. Biol., 58: 1379-1391.

Reynolds, J., C. Souty-Grosset \& A. Richardson. 2013. Ecological roles of crayfish in freshwater and terrestrial habitats. Freshw. Crayfish, 19(2): 197-218.

Riek, E.F. 1971. The freshwater crayfishes of South America. Proc. Biol. Soc. Wash., 84: 129-136.

Rudolph, E. 1997. Aspectos fisicoquímicos del hábitat y morfología de las galerías del camarón excavador Parastacus nicoleti (Philippi, 1882) (Decapoda, Parastacidae) en el sur de Chile. Gayana Zool., 61(2): 97-108.

Rudolph, E. 2010. Sobre la distribución geográfica de las especies chilenas de Parastacidae (Crustacea: Decapoda: Astacidea). Bol. Biodivers., 3: 32-46.

Rudolph, E.H. 2013. Freshwater malacostracans in Chilean inland waters: a checklist of the Chilean Parastacidae (Decapoda, Astacidea). Crustaceana, 86: 1468-1510.

Rudolph, E. \& A. Almeida. 2000. On the sexuality of South American Parastacidae (Crustacea, Decapoda). Invest. Rep. Dev., 37(3): 249-257

Rudolph, E. \& K.A. Crandall. 2005. A new species of burrowing crayfish, Virilastacus rucapihuelensis (Crustacea: Decapoda: Parastacidae), from southern Chile. Proc. Biol. Soc. Wash., 118(4): 765-776.

Rudolph, E. \& K.A. Crandall. 2007. A new species of burrowing crayfish Virilastacus retamali (Decapoda: Parastacidae) from the southern Chilean peatland. J. Crustacean Biol., 27(3): 502-512.

Received: 12 December 2014; Accepted: 15 July 2015
Rudolph, E. \& K.A. Crandall. 2012. A new species of burrowing crayfish, Virilastacus jarai (Crustacea, Decapoda, Parastacidae) from central-southern Chile. Proc. Biol. Soc. Wash., 125(3): 258-275.

Rudolph, E. \& H. Rivas. 1988. Nuevo hallazgo de Samastacus araucanius (Faxon, 1914) (Decapoda, Parastacidae). Biota, 4: 73-78.

Rudolph, E. \& C. Rojas. 2003. Embryonic and early postembryonic development of the burrowing crayfish, Virilastacus araucanius (Faxon, 1914) (Decapoda, Parastacidae) under laboratory conditions. Crustaceana, 76(7): 835-850.

Rudolph, E., F.A. Retamal \& A.W. Martínez. 2007. Partial protandric hermaphroditism in the burrowing crayfish Virilastacus rucapihuelensis Rudolph \& Crandall, 2005 (Decapoda, Parastacidae). J. Crustacean Biol., 27(2): 229-241.

Straelen, V. van. 1942. À propos de la distribution des écrevisses, des homards et des crabes d'eau douce. Bull. Mus. Roy. Hist. Nat. Belgique, 18(56): 1-11.

Valencia-López, D.M., F. de P. Gutérrez-Bonilla \& R. Álvarez-León. 2012. Procambarus clarkii Girard, 1852 (Decapoda: Cambaridae), 5.3 Crustáceos exóticos. In: F. de P. Gutiérrez-Bonilla, C.A. LassoAlcalá, M.P. Baptiste, P. Sánchez-Duarte \& A.M. Díaz-Espinosa (eds.). VI. Catálogo de la biodiversidad acuática exótica y trasplantada en Colombia: moluscos, crustáceos, peces, anfibios, reptiles y aves. Bogotá D.C., pp. 275-321. 